PNL-10215

UC- 900

\title{
Developing a Chemical Industry Strategy: State-of-the-Industry Profile
}

\author{
S. C. Weiner \\ M. G. Woodruff \\ A. K. Johnson
}

October 1994

Prepared for

the U.S. Department of Energy

under Contract DE-AC06-76RLO 1830

Pacific Northwest Laboratory

Richland, Washington 99352

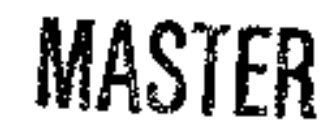

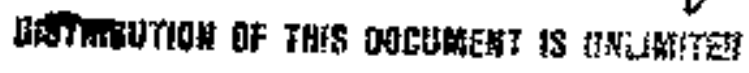

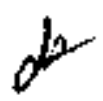




\section{DISClAIMER}

This report was prepared as an account of work sponsored by an agency of the United States Government. Neither the United States Government nor any agency thereof, nor any of their employees, make any warranty, express or implied, or assumes any tegal flablitty or responsibility for the accuracy, completeness, or usefulness of any information, apparatus, product, or process disclosed, or represents that its use would not infringe privately owned rights. Reference herein to any specific commercial product, process, or servlce by trade name, trademark, manufacturer, or otherwise does not necessarily constitute or imply its endorsement, recommendation, or favoring by the United States Government or any agency thereof. The views and apinions of authors expressed herein do not necessarily state or reflect those of the United Stater Government or any agency thereof. 


\section{DISCLAIMER}

Portions of this document may be illegible in electronic image products. Images are produced from the best available original document. 


\section{Executive Summary}

As part of its "Industries of the Future" program, the U.S. Department of Energy (DOE) Office of Industrial Technologies (OIT) is developing a strategy to focus its technology development efforts that are relevant to the chemical industry on the highest-priority needs of that industry. Industry involvement is an important part of the strategy development process. To develop the chemical industry strategy, OIT will work with the industry to identify jts vision of the jndustry's future and the techoology needs that flow from that vision. An industry-initiated and industry-led effort is currently underway to define a vision and roadmap for change for the chemical industry. This effort, along with additional discussions with incustry leaders to identify specific technology needs, will provide OrT with the information it needs to work jointly with industry to develop the strategy. Ulimately, the strategy will help OIT orient its chemjcal industry-related programs towatd those technology needs that are both critical to the industry's future and that are best met through a governinentindustry partnership.

This report, the first element of the strategy development effort, provites background information on the driving forces affecting the chemical industry, the challenges and opportunities they represent, and how the industry is responding to them. To assess the incustry's perspectives on these topics, Pacific Northwest Laboratory (PNL) reviewed a number of industry sources, including the annual reports of 31 major chemical companjes. These were supplemented with data from other sources where appropriare.

This review indicates that the driving forces exerting pressure on the chemical indestry include economic and competitive conditions, globalization, environmental requirements, and changing customer demands. These can be grouped into two categories: economic/competitiveness trends and environmental trends.

The economic/competitiveness trends affecting the U.S. chernicals industry include (Lenz 1994):

- supply/demand mismatches resulting from slow U.S. and global economic growth and the giobalization of supply

- increasing development of donestic chemical inchustries by other courntries, exacerbating global oversupply and shrinking export markets

- decreasing pricing flexibility-prices are now set giobally for many chemicals, and the weak economic clinate has made customers less willing to accept price increases.

In response to these trends, the industry has cut costs and achieved gains in productivity; focused on customer satisfaction; increased quality; and continued global investment. Employment has failen at the same time that laber productivity has risen. In addition, firms have moved into the more profitable 
specialty chemicals market, and have put less focus on basic, commodity chemicats. One consequence of this movement is a shift of research expenditures from basic chemistry to the technical service that custoners demand with specialty chemicals.

Environmental drivers involve regulafory jnitiatives as well as increased public axtertion to environmental issues. These two drivers have created strong pressure on the environmental front, which is manifested in two ways:

- as mandates governing chemical industry operations, which are forcing companies to itvest in costly environment-related upgrades

- as demands by customers for products that are developed using environmentally benign processes and that help themn meet environmental requirements.

Meeting environmental requirements has consumed an increasing share of the industry's capital investment; this trend is likely to continue with the March 1, 1994, issuance of a new Environmental Protection Agency (EPA) rule requiring chemical plants to reduce atmospheric entissions of toxic substances by $88 \%$.

The industry is responding to environmental trends by increasing environmental spending on pollution abatement and control, working to improve the environmental perfornance of its mamufacturing processes, and working with clients to develop new products that conform to new regulations. Industry-wide programs, such as Responsible Care ${ }^{*}$, have been developed to improve environmental performance and testore public trust.

The industry's pattern of research and developmenk (R\&D) expenditures reflects its response to economic/competitive and environmental drivers. Overall, spending for R\&D within chemical companies has been gradually decreasing. a trend that is expected to cominue until at least the middle of the decade. This decrease is in part a response to the recession that took hold in 1991; R\&D investments are not generally viewed as Jevenue producing and are thus vulnerable when cost-cutting is required (Thayer 1994). In addition, in response to the shift to specialty chemicals, more funding has been allocated to technical service costs and to product extensions or upgrades, jeaving less money available for R\&D activities in areas such as new chemistry and knowledge building. Finaly, the need for increasing investments for environmental needs has also squeezed R\&D budgets antong chemical firms.

Currently most R\&D dollars-67\% in 1991 mare consumed by technical service costs and product extensions and upgrades, which provide individual companies with competitive edges. Less than $25 \%$ of the industry's R\&D spending goes into new processes and new chemistry, compared with $50-65 \%$ in 1981 . 
Mary companies also are changing how they do R\&D, opting to contract to outside organizations and participate in joint R\&D ventures with other companies. Firms have also begun to tap into the resources of the federal laboratories, and industry has begun to explore opportunities to partmer with the federal govermment in areas of mutual interest. The OIT's "Industries of the Future" program buitds on this movement toward collaboration among fims and with the federal governunent. The program will advance the state of chemical technology by (DOE 1994):

- catalyzing and facilitating collaborative, integrated planning and implementation of technologies by industry, government, and other participants

- conducting research, development, and deployment (RD\&D) through partnerships with industry participants as well as by focusing competencies of the federal laboratories on industry applications

- disseminating techrology and information to stimulate broad commercialization of technologies.

As the next steps in the strategy development effort for the chemical industry, OrT will discuss technology needs with industry leaders in the context of the drivers discussed in this report, the vision being developed by industry representatives, and recent input from the industry on technology needs. OIT will hold a peblic workshop to review these results with stakeholders and seek feedback and additional input. Finally, OIT will use the inpet from this process to develop a strategy for conducting high-priority RD\&D collaboratively with industry and other partners. 



\section{Contents}

Executive Summary $\ldots \ldots \ldots \ldots \ldots \ldots \ldots \ldots \ldots \ldots \ldots \ldots \ldots \ldots \ldots$

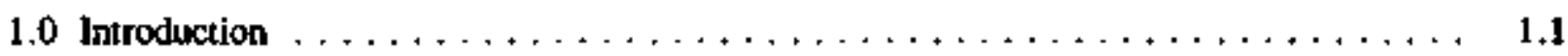

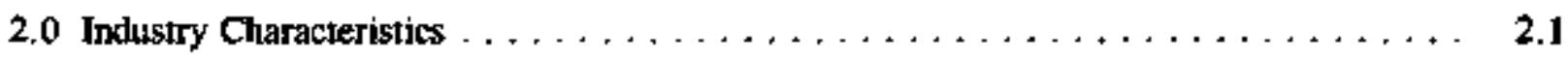

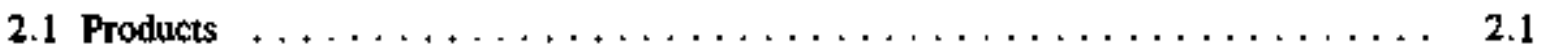

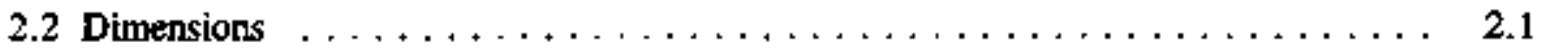

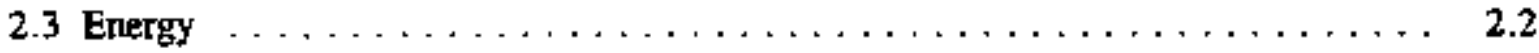

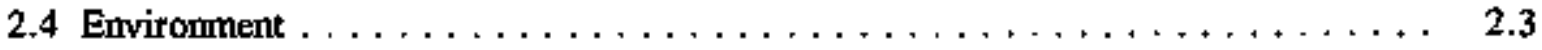

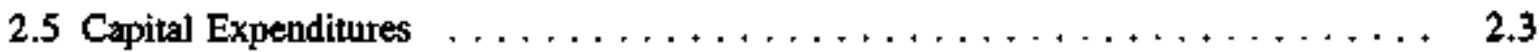

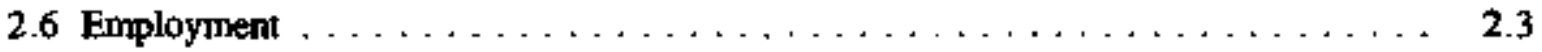

2.7 International Trade $\ldots \ldots \ldots \ldots \ldots \ldots \ldots \ldots \ldots \ldots \ldots \ldots \ldots$

2.8 Stakeholders $\ldots \ldots \ldots \ldots \ldots \ldots \ldots \ldots \ldots \ldots \ldots \ldots \ldots \ldots \ldots$

3.0 Industry Drivers and Strategies: Productivity, Globalization, and the Environment Dominate .

3.1 Drivers: Economic and Competitive Pressures are High, Exacerbated by Globalization

3.2 Strategies: Companies Emphasize Productivity Gains and Customer Satisfaction . .

3.2.1 Strategy: Cost-Cuting and Productivity Gains are Necessary to Improve Profitability

3.2.2 Strategy: An Increasing Focus on Customer Satisfaction is Critical to Company Success

3.2.3 Strategy: Product and Process Quality Help U.S. Companies Compete

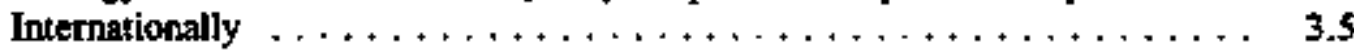

3.2.4 Strategy: Global Investment Continues $\ldots \ldots \ldots \ldots \ldots \ldots \ldots \ldots \ldots \ldots$

3.3 Driver: Environmental Requirements Affect Capital Investnent and Prohuct Development 
3.4 Strategy: More Spending is Required on Environmental Protection $\ldots \ldots \ldots \ldots$

3.5 Strategy: Industry-Wide Programs Help Ensure Environtrentał Compliance . . . . 3.8

4.0 Effects of Drivers and Strategies on Industry Research and Development $\ldots \ldots \ldots \ldots$. . .

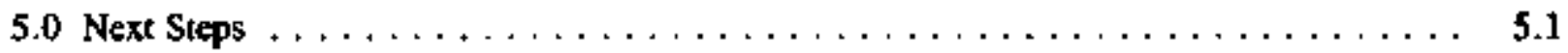

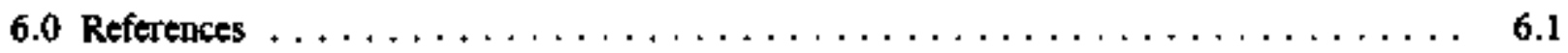

Appendix A - Tables $\ldots \ldots \ldots \ldots \ldots \ldots \ldots \ldots \ldots \ldots \ldots \ldots \ldots \ldots$ 


\section{Tables}

$2 . \pm 1993$ U.S. Chemical Trade by Industry Segment $\ldots \ldots \ldots \ldots \ldots \ldots \ldots \ldots$

3.1 Environmental Spending by Company $\ldots \ldots \ldots \ldots \ldots \ldots \ldots \ldots \ldots \ldots$

3.2 Capital Expenditures for Pollution Abarement in the Chemicat lndustry $\ldots \ldots \ldots \ldots$

4.1 R\&D Budget Allotments $\ldots \ldots \ldots \ldots \ldots \ldots \ldots \ldots \ldots \ldots \ldots \ldots \ldots \ldots$

A.1 Companies Whose 1992 Annual Reports Were Reviewed $\ldots \ldots \ldots \ldots \ldots \ldots \ldots$

A.2 Standard Industrial Classifications Major Group 28 - Chemicals and Altiod Products . . . A.2

A.3 The Chemicals Industry Today $\ldots \ldots \ldots \ldots \ldots \ldots \ldots \ldots \ldots \ldots \ldots \ldots$

A.4 Major Environmenta! Statutes Affecting the Chemical Industry $\ldots \ldots \ldots \ldots \ldots \ldots \ldots$. . . . .

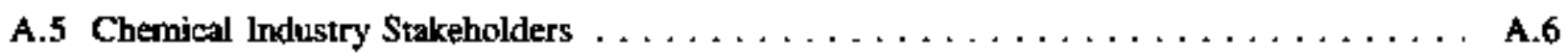

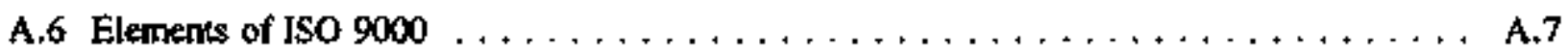

A.7 ISO 9000 Certification at U.S. Chemical Companies $\ldots \ldots \ldots \ldots \ldots \ldots \ldots \ldots$

A.8 Guiding Principles of Responsible Care $\ldots \ldots \ldots \ldots \ldots \ldots \ldots \ldots$ 


\subsection{Introduction}

The chemical industry, the largest industrial consumer of energy in the United States, has benefited from U.S. Department of Energy (DOE) efforts to develop technology to improve industrial energy efficiency. Currently, DOE's Office of Industrial Technologies (OIT) is focusing its technology development efforts to be even mare effective in helping the industry improve its long-term competitiveness. The Pacific Northwest Laboratory (PNL) ${ }^{(a)}$ is assisting OIT in developing a chemical incustry strategy to focus technology development efforts relevant to the chemical industry on the highest-priority needs of that industry. This report represefts an initial effort in developing such a strategy.

This strategy development effort is part of the DOE's "Industries of the Future" program, which is designed to align federal investments in technology research, development, and deployment (RD\&D) with the needs of technology users in the pivate sector (DOE 1994). The industries targeted by the program are developing, with OIT facilitation, visions of their futures that will serve as the basis for shaping a portfolio of RD\&D activities focused on high-priority technologies.

The elements of the strategy development effort for the chemical industry are as follows:

- initial characterization of the chemical industry, the forces that are driving it, and the incustry's vision of how thase forces are shaping its futhre

- discussions with industry representatives to obcain feedback and imput on

- the driving force analysis

- the industry's vision of its future

- the technology-related needs that industry must meet to respond to driving forces and achieve its vision

- the subset of those needs that might best (or only) be met with government as a partner

- the issues that must be resolved to increase the effectiveness of government/industry partnership efforts

- identification of detailed technology needs (in cooperation with industry) in high-priority areas

- development of a strategy for working in partmership wit the chemical industry on technologyrelated programs that will achieve those goals common to the chenical industry and the U.S. government.

(a) Pacific Northwest Laboratory is operated by Battelle Memorial Institute for the U.S. Departmert of Energy under contract DE-ACO6-76RLO 1830. 
A key element of the "Industries of the Future" program is the involvement of industry participantis throughout the strategy devejopment process. The Chemical Manufacturers Association (CMA), the American Chemical Society (ACS), the American Institute of Chemical Engineers (AIChE), and other groups are currently leading an industry-initiated effort to develop a vision and roadmap for change for the U.S. chemical industry. This effort, which is occurring concurrent with the "Industries of the Funuren program for the chemical industry, will provide vital input to the OIT program. (a) To develop its strategy under this program, OrT will rely on this input as well as additional input obtained from industry representatives.

This report represents the first element of the strategy development effort for the chemical industry. It profiles the driving forces impacting the industry, the challenges and opportunities they present, and how industry is responding to them. Key industry characteristics, such as energy use, envirommental constraints, and investment, are described in Section 2.0. Section 3.0 discusses major factors influencing industry actions, such as globatization of markets, increased competitive pressures, and stakeholder pressures. Their influence on industry capital investment and research and development spending are described in Sections 4.0 and 5.0. Section 6.0 presents conclusions, and Section 7.0 addresses next steps in the strategy development process. Appendix A provides supporting tables.

To prepare the report, PNL staff reviewed industry overviews, forecasts, and statistics in trade journals and reports and Department of Commerce publications. This analysis was supplemented with discussions with chemical industry analysts and trade associations and a review of the 1992 anntal reports of 31 major chemical companies (see Table A.1) to identify company goals and the strategies they are using to achieve then. To assess the chemical industry's perspectives on these topics, PNL emphasized industry sources in its review, supplementing these with data from other sources where appropriate.

(a) The industry and OIT efforts are closely linked. The leader of the PNL effort to support OIT's strategy development effott for the chenical industry is a participant th the industry group developing the vision and roadmap for change for this industry. 


\subsection{Industry Characteristics}

This section describes characteristics of the chemical industry, including its products, dimensions, energy consumption, environmental mandates, employment, internationa! trade, and stakeholders.

\subsection{Products}

The chemical industry is extremely diverse. It produces a variety of products that may be viewed as part of three broad categories:

- basic chemicals-e.g, acids, alkalies, salts, and organic chemicals

- chemical products used in further manufacture (intermediates)-e.g., synthetic fibers, plastic materials, and color pigments

- finished chemical products used for nlitmate consumption-e.g., diugs, cosmetics, and soaps-or used as materials in other inchstrtes-e.g. paints, fertilizers, and explosives.

The 4-digit industries in Standard Industrial Classification (SIC) 28 are shown in Table A.2. A broader definition of the industry bejond SIC 28 includes otber chenically processed products such as semiconductors, carton paper, and inked ribbons, which encompass an even more diverse industry. However, this strategy development effort focuses on the chemical sub-industries included in SIC 28

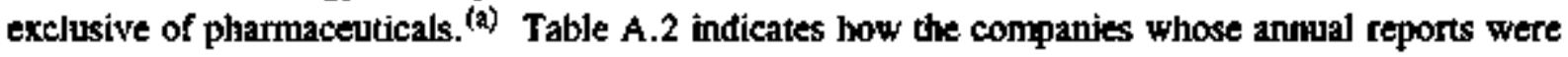
reviewed are distributed within SIC 28.

\subsection{Dimensions}

Statistics on the dimensions of the chemical industry are listed in Table A.3. The chemical industry is among the largest industries in the United States and is a major driving force in the U.S. econony. Total industry revenues exceeded \$316 billion in 1992 (CMA 1993), while shipments exceeded $\$ 295$ billion (Chemical Week 1993b). In 1990, the industry accounted for about $1.8 \%$ of the U.S. gross domestic product and about 23\% of total world chemical production (CMA 1993).

(a) Although industry-wide statistics cited in this report include the pharmaceuticals industry unless stated otherwise, pharmaceuticals are not expected to be a focus of the chemical industry strategy. 
In all, U.S. chemical companies produce over 70,000 different chemical products at over 12,000 plants (CMA 1993). United States companies have more than 2,800 facilities abroad, and 1,700 foreign subsidiaries or affiliates operate in the United States.

The chemical industry itself is the largest purchaser of its own chemical production, consuming 24\% of the industry's output in 1992 (CMA 1993). The rest of the manufacturing sector purchased $29 \%$ of its output, with the remaining output going to non-manufacturing industries and consumers. The high fraction (over $50 \%$ ) of output used in the manufacturing sector makes chemical industry competitiveness highly dependent on the competitiveness of manufacturing as a whole.

\subsection{Energy}

The chemical industry is the largest industrial consumer of energy for heat and power purposes in the United States and the second largest consumer of energy feedstocks (after petroleum refining). In 1992, the industry consumed about 5.6 quads of energy for fuel, power, and fedstocks, about $7 \%$ of total U.S. energy consumption (CMA 1993). About 52\% of this went for fuel and power needs, with $48 \%$ for feedstocks. Consumption for heat and power represented about $18 \%$ of total manufacturing consumption for this purpose.

Four segments of the chenical industry-inorganic chemicals, plastics, organic chemicals, and agriculural chemicals-dominare industrial energy use. In 1989, these four industry segments consumed almost $87 \%$ of the total fuel and electricity purchased by the industry as a whole. In the same year, these industry segments consumed over $90 \%$ (in kWh) of the electricity purchased by the chemical industry (DOC 1989).

Over time, feedstocks have grown as a fraction of energy use. In 1970 , feedstocks were $39 \%$ of the total energy use in the chemical industry; by 1991, this fraction had grown to $48 \%$. This trend reflects increased demand for petrochemicals to create plastics and other materials as wel] as increased energy efficiency in production processes (CMA 1992). Measured in terms of energy use per unit of output, efficiency in the use of energy for fuel and power has increased by $51 \%$ since 1974 (CMA 1992). This increase is due both to improved techology and energy management and to changes in the mix of products toward fine chemicals, whose production is less energy intensive than basic, upstream comunodity chenticals.

Energy intensity varies widely anong seginents of the chemical industry. Some portions of the industry are very energy intensive. For example, the energy needed for fuel and power in the iadustrial gases industry represents from 40 to $50 \%$ of total operating costs. Other parts of the industry are relatively non-energy intensive. For example, energy use in the production of inorganic chemicals amounts to less than 10\% of production costs (OTA 1993). 


\subsection{Environment}

The chemical industry is subject to numerous statutes and regulations designed to protect and restore the environment (see Table A.4). These govem discharges to air, water, and land: management of hazardous waste from generation to disposal; cleantp of hazandous waste sites; testing and manufacture of chemical substances and mixtures; and generation, storage, purchase, and shipment of hazardous material. Mote recent regulatory trends emphasize waste avoidance and pollution prevention over traditional end-of-the-pipe controls.

The chemical industry has been required to make sigmificant capital investments to comply with environmental protection requirements associated with its operations. As a result of these expendjtures, the CMA reports that releases of a core list of Toxic Release Inventory chemicals from CMA member comparies decreased 35\% between 1987 and 1991 , an anmal decrease of $10.2 \%$. Over the same period, transfers for treatment and disposal decreased $37 \%$ and judustry production increased $11 \%$ (CMA 1993). ${ }^{\text {(a) }}$

The industry also has spent substanial amounts to clean up inactje hazardous waste sites under the Comprehensive Environmental Response, Compensation, and Ljability Act, aiso known as Superfund. The industry has supported reform of this law to, among other things, replace with a proportional liability scheme the current strict, joint and several liability scheme wherein any party who contributed waste to a Supertinnd site can be held liable for the total cost of the cleanup, regardless of the arnount of waste that party contributed (AIChE 1993).

\subsection{Capital Expenditures}

The chemical industry is by its nature very capital intensive, requiring heavy investonents in equiprnent, processes, and technology . In 1992, gross capital stocks per employee in the chemical industry were $\$ 197,800$, more than twice the amotunt for U.S. manufacturing as a whote (CMA 1993). New capital expendiures in 1992 totaled $\$ 23$ billion (CMA 1993). By and large, aggregate capital spending has increased greatly since the early 1980 s, although indjvidual companies' expenditures may fluctuate from year to year, depending on their financial situation, whether they have added any new facilities within the past year, and the company's area of specialty.

\subsection{Employment}

Over one million people are employed in the chenical industry, though employment has been flat over the past 10 years, matching trends in manufacturing as a whole (CMA 1993). The

(a) CMA member companies account for more than $90 \%$ of basic U.S. industral chemical capacity. 
pharmaceuticals sector, in fact, is the only sector showing annual employment increases over that period. The early $1990 \mathrm{~s}$ saw employment cutbacks of approximately $4 \%$ at 21 major chemical companies. Labor productivity (output per labor hour) has increased steadily over the past decade.

\subsection{Intemational Trade}

The U.S. chemical industry is a substantial contributor to manufacouring exports and has had a trade surplus every year since 1983. In 1993, the industry had exports of almost $\$ 45$ billion and imports of about $\$ 29$ billion, for a trade surpjus of almost $\$ 16$ bjilion (Anderson 1993). However, this surplus has been eroded in recent years by weak overseas economies. which darspened exports, and growing imports (Lenz 1994). (The U.S. economy was less weak than many others, so its imports grew more than its exports.) The chemical trade surplus dropped over $13 \%$ in nominal terms from 1991 to 1992 and $3.5 \%$ from 1992 to 1993 . Also, the compesition of exports has been changing. Exports of organics, the largest export category, have fallen slightly while exports of specialty chemicals, such as dyes and coloring materials, ssential oils, peffumes, toilet preparations, and cleaning materials, are growing faster than the all-chemical average, though they remain a small fraction of total exports (Anderson 1993). The level and fraction of trade associated with each industry segment are indicated in Table 2.1 .

In 1992, the largest single-country market for U.S. chemicals was Canada (16.6\%), followed by Japan (10.7\%) and Mexico (7.1\%). As a bloc, the European Union (EU) ${ }^{(a)}$ is the U.S. chemical indestry's largest single market (27.4\%). Exports to Mexico have been growing sceadily, doubling over the last five years; the North American Free Trade Agrement is expected to stintulate increased track with Mexico and Canada.

By region, most exports went to Western Europe (about 30\%); Esst Asia and Larin Anerica received about $17 \%$ of exports. Growth in exports to East Asia is slowing as these comntries begin to supply parts of their own markets from their own chenical plants (CMA 1993; Anderson 1993).

\subsection{Stakeholders}

Many groups have a stake in the performance of the chemical industry, including shareholders, employees, customers, retirees, conmumities/neighbors, suppliers, regulators, industry and trade associations, ultimate consumers, the financial comununity, the media, joint venture partners, and others. Tabje A.5 provides examples of these stakeholder groups.

(a) Formerly known as the Europesn Community. 
Table 2.1. 1993 U.S. Chemical Trade by Industry Segment (billions of U.S. dollars)

\begin{tabular}{|c|c|c|c|c|c|c|}
\hline & \multicolumn{2}{|c|}{ Exports } & \multicolumn{2}{|c|}{ Imports } & \multicolumn{2}{|c|}{ Surplus } \\
\hline & $\begin{array}{c}\text { Level } \\
\text { (\$ billions) }\end{array}$ & $\begin{array}{c}\text { Share } \\
(\%)\end{array}$ & $\begin{array}{c}\text { Level } \\
\text { ( } \$ \text { billions) }\end{array}$ & $\begin{array}{c}\text { Share } \\
(\%)\end{array}$ & $\begin{array}{c}\text { Level } \\
\text { (\$ bitlions) }\end{array}$ & $\begin{array}{l}\text { Share } \\
(\%)\end{array}$ \\
\hline Organic chemicals & 11.0 & 24.6 & 9.3 & 32.0 & 1.7 & 10.8 \\
\hline Primary plastics & 7.3 & 16.3 & 2.7 & 9.3 & 4.6 & 29.3 \\
\hline Pharmaceuticals & 5.7 & 12.8 & 4.1 & 14.2 & 1.6 & 10.2 \\
\hline Inorganic chemicals & 4.1 & 9.2 & 3.2 & 11.1 & 0.9 & 5.7 \\
\hline Nonprimary plastics & 3.3 & 7.3 & 2.1 & 7.3 & 1.1 & 7.3 \\
\hline Oils/perfumes/cleaners & 3.0 & 6.6 & 1.8 & 6.0 & 1.2 & 7.7 \\
\hline Dyeing/tanning/coloring & & & & & & \\
\hline Materials & 2.0 & 4.4 & 1.7 & 5.9 & 0.3 & 1.6 \\
\hline Fertilizers & 1.8 & 3.9 & 1.2 & 4.0 & 0.6 & 3.7 \\
\hline Other & 6.7 & 14.9 & 3.0 & 10.2 & 3.7 & 23.6 \\
\hline Total & 44,9 & 100 & 29.2 & 100 & 15.7 & 100 \\
\hline
\end{tabular}

Soutce: Anderson 1993.

The interests of various stakeholder groups may conflict with one another and with the needs of the industry itself. For example, stringent environmental laws promoted by regulators and public interest groups are aimed at protecting the environment but may damage industrial competitiveness relative to some foreign compexitors. Likewise, company shareholders' interests in the short-term profitability of a particular firm may conflict with the local community's interest in the company's long-term success. In spite of such conflicts, sharebolder interests often become the most important near-term driver for industry leaders. As much as 75\% of a company's common stock may be in the form of institutional holdings. Pressures to ensure near-term profitability through cost reductions have resulted in significant downsizing througbout the industry. At the same time, public and regulatory pressures have motivated the chemical industry to take active steps to reduce the environmental impacts of its operations and to work with communtty representatives in doing so. 


\subsection{Industry Drivers and Strategies: Productivity, Globalization, and the Environment Dominate}

The driving forces exerting pressure on the chentical industry joclude econonic and competitive conditions, globalization, environmental requirements, and changing customer demands. These forces are intecrelated. For example, customer demands have shified toward thore enviromentally benign products; increases in spending to meet environmental requirements can affect international competitiveness; and globalization of markets affects the competitive climate in which U.S. companies must operate. The most important aspects of the major driving forces are described in this section in two separate categories, economicsicompetitiveness and environment, but their interrelationships should be kept in mind. Likewise, industry actions in response to these ditivers, discussed in the context of individual drivers, usually are directed at multiple drivers.

\subsection{Drivers: Economic and Competitive Pressures are High, Exacerbated by Globalization}

Economic forces and competitive pressures have always ben major drivers for the chemical industry. They are especially important today in light of the trend toward a global industry, which has been fostered and enhanced by world economic growth, the reduction of trade barriers, and advances in telecommunications and transportation. Competitive pressures increase with globalization of markets and expansion of regional players to foreign markets so that all suppliers compete everywhere.

Several trends are affecting the profitability and competitiveness of the U.S. chemical industry, as described below (Lenz 1994):

- supply/demand mismatches resulting from slow U.S. and global economic growth and the globalization of supply

- increasing development of domestic chemical industries by other countries, exacerbating global oversupply and shrinking export markets

- decreasing pricing flexibility-prices are now set globally for many chemicals, and the weak economic climate has made customers less willing to accept price increases.

Slow growth in the industries served by the chemical industry has affected chemical sales and profits. For example, slowdowns in the alumimim and textile industries have depressed demands for canstic soda frosa the chlor-alkali industry (SIC 2812) (Chemical Week 1993a). Flat overseas economies have adversely affected export makkets for U.S. companies. 
In addition to such business cycle effects, however, worldwide overcapacity in some industry segments has led to declining prices and lower profit margins and a trend toward company mergers. For example, low energy prices and worldwide overcapacity in the petrochemical industry are leading to a global consolidation of the refining industry that will ultimately result in fewer and leaner petrochemical companies. This trend is likely to worsen as some overseas markets, most notably in Asia, begin to supply their own petrochemicals and other chemicals, further shrinking export markets for U.S. products. Globalty competitive chemical industries are emerging in newly industrializing countries such as Singapore, South Korea, Tajwan, and Thailand, reducing their value as expont markets for U.S. companties.

Recent economic conditions and low inftation rates have lefi industrial customers unwilling to accept price increases for many chemicals, particularly petrochemicals, even in the face of increasing input prices. Also, industrial customers have demanded discounts when feectstock prices have declined, even those custonters who purchased chemicats based on other inputs whose prices did not decline. Petrochenical producers typically enjoy only a short period (as short as a week) of improved profitability when feedstock prices fall (Ainsworth 1993).

Prices for many chenicals are set globally, which also has hampered producers" ability to set prices and thus their profitability. As one industry spokesman stated, prices now determine costs. That is, prices are set globally, and companies must make adjustments to input costs (e.g., by laying off workers) to remain profitable (CMA 1994).

Other economic drivers among highly capitalized companies include a need to pay down debt, partly in response to pressure from the financial community. One petrochemical company included in its annual report 11 quotes from various financial analysts highlighting their positive view of the company's efforts to strengthen its profitability (Occidental Petroleum Corporation 1993).

Volatility in product demand, which affects profitability, reflects changing market and economic conditions as well as increased emphasis on nonhazardous products. Changes in worldwide economic conditions can cause significant product dernand changes. For example, upheavals in some parts of the world have eliminated the market for certain products. Also, downturns in domestic intustries such as the defense and aerospace industries have decreased customers' profit margins and thus their demands. At the same time, significant new markets are opening up in Eastern Europe and Asja that comparies feel they must respond to if they are to remain competitive and profitable. In addition, the increased demand for more products that are less hazardous to the environment and to production workers is increasing the market for some chemicals, such as bronide-based water treatment chemicals, and decreasing the markets for others, such as chlorine (see the discussion of environmental strategies). All in all, economic conditions and environmental requirements bave created a business that can be characterized as volatile, and this volatility was cited repeatedly in the annual reports as a challenge to the chemical industry. 


\subsection{Strategies: Companies Emphasize Productivity Gains and Customer Satisfaction}

In the 1980 s, the chemical industry restructured itself by closing inefficient and obsolete plants, streamlining production processes, reorganizing corporate activities, and placiog more enuphasis on specialty chemicals with high profit margins (OTA 1993). Yet, as discussed, the 1990s have presented significant economic and competitive challenges that were exacerbated by increasing globalization. Companies responded to economic and competitive drivers by cutting cosss and achieving gains in productivity; focusing on customer satisfaction; increasing quality; and continuing global investment. These strategies had important implications for the level and nature of expendirures for capital invesument and research and development, as discussed in Sections 4.0 and 5.0.

\subsubsection{Strategy: Cost-Cutting and Productivity Gains are Necessary to Improve Profitabillty}

As noted earlier, many companies have found it difficult to raise prices and so have focused on cutting input costs and iumproving overall productivity to lncrease profitability. Managing costs and investing in productivity-enhancing equipment were necessary for bottom-iine gains in 1993 (Chemical Week 1993b).

Providing vaiue to stockholders and beconing low-cost producers were recurring themes in the annual reports. Many companies had specific goals to achieve percentage returns on shareholder equity that ranged from the mid-teens to $20 \%$ (Monsanto 1993; B.F. Goodrich 1993). Sixty-five percent of the companies whose reports were reviewed described planned cost-control meastires that inciuded divesting assers to retuce debt, reducing reliance on cyclical products, closing unprofitable or outdated plants, streamlining operations, cutting jobs, encouraging early retirement, and reducing spending on facilities and research.

Restructuring and downsizing in response to economic and competitive presstures have resulted in declines in employment, particularly at 21 large companies where employment decreased $4 \%$ in 1992 (C\&EN 1993b). At the same time, labor productivity has been increasing steadily for the industry as a whole; the workers left behind after restructuring are being asked to do more. Greater enmployee productivity is encouraged through means stich as financial incenrives and awards. Performance-based compensation can put a significant share of an entuloyee's compensation at risk, depending on the profitability of the particular business unit and the corporation as a whole.

Many firms adso are focusing on strategic businesses, either by selling non-strategic businesses or acquiring other, complementary businesses. 


\subsubsection{Strategy: An Increasing Focus on Customer Satisfaction is Critical to Company Success}

Companies have responded to economic and competitive pressures by focusing on customer satisfaction as crucial to company success. Providing quality products ard services was an implicit or explicit goal for many of the companies whose annual reports PNL reviewed. This was sometimes stated as a goal to maintain product quality in the face of needed cost-cutting.

Underlying product quality goals is a focus on customer sarisfaction and beconing the first choice supplier for a company's customers. A related recurring theme was working with customers as partners to solve technical problems and develop products that meet the customers' needs, particularly those related to environmental recquirements. Today, product development begins with identifying customer needs. Various companies have implemented cross-functional team strategies that combine expertise from many disciplines-sales, technisal service, research, engineering, and logisties-to enable the conpany to meet customers" product design requirements more easily (ARCO Chemical Company 1993). Being indispensable to customers' success is seen as a high priority. This attitude reflects the sinuation in Japan, whose model of close, long-term supplier/customer relationships is a cnucial element of that country's economic success. In the face of such relationships, crestomers may be less willing to switch suppliers as prices fluctuate.

In addition, most companies are working to improve on-time delivery and reduce customer complaints by streamiining the supply-chain management process. Customer satisfaction surveys are used by one major enterprise to obtain direct feedback from clients regarding the quality of the company's performance (Nalco Chemical Company 1993). Clients grade both this firm and its competitors on a variety of criteria that they consider important.

The degree of focus on interaction with customers also has been affected by shifts among the types of chemicals sold by the industry. The output of chemical companies is typically divided into two categories: basic or commodity chemicals, which are sold on the basis of price, and speciaity chemicals, which are sold on the basis of performance. Compared with commodity chemicals, specialty chemicals are more profitable and less cyclical. In an effort to combat the cyclicality of the industry, in the 1980 s most conminodity chemical manufacturers made forays into the downstream specialty chemicals business (Anderson and Ayers 1992). However, the profitability life span of specialty products is shorter than that of commodity chemicals, and custcriners typically demand closer collaboration and higher levels of technical service with these products (Anderton and Ayers 1992). Also, even the specialty chemicals market is experiencing increased pressure on profit margins. The market as a whole has been becoming more competitive (Anderson and Ayers 1992).

Shifts to specialty chemicals have been reflected in an increasing focus on customer satisfaction and increasing shifts of research expenditures from basic chemistry to technical service (see Section 5.0). 


\subsubsection{Strategy: Product and Process Quality Help U.S. Companies Compete Internationally}

Firms also are responding to econonic and competitive pressures by increasing the quality of products and processes. Many of the firms surveyed are seeking certification through the International Organization for Standards (ISO) 9000 program, which was initiated in 1987 as a series of ive international standards for quality management and quality assurance (QA). The ISO standards establish a benchmark for QA practices for nearly all phases of the production process, inciuding design, manufacture, installation, packaging, and marketing (see Table A.6). Currently, approximately 35,000 ISO registrations exist in Europe, conpared with only 2,000 in the United States, although the number of new registrations grew by $500 \%$ in the United States during 1992 (SOCMA 1993). Some major U.S. chenical companies that have achieved ISO certification are listed in Table A.7.

In addition to improving company performance, implementation of 1SO standards can help U.S. firms compete more effectively with international chenical companies, since the EU may soon require compliance with ISO 9000 standards for companies that make products in or export goods to EU member countries (Grant Thornton 1992). Companies that are part of 1509000 also agree that the program helps them cut costs and boost on-time delivery. A recent survey of 1,679 companies in the Unites States and Canada having $1 S O$ registrations reported an average anmual savings of $\$ 179,000$ as a consecuence of registration, and most companies expected to recoup the costs of registration within 40 months (SOCMA 1993).

\subsubsection{Strategy: Global Investment Continues}

Companies feel pressurre to continue glabal investnent. Regional companies carnot compete in this global market and feel pressure to expand. Expansion in turn reguires increased capital expenditures for plants and equipenent, for acquisitions, or for both.

In a recent speech to a meeting of the American Institute for Chemical Engineers, a petrochemical industry executive echoed the philosophy underlying most discussion of industry globalization trends:

As a U.S. company, why do we invest outside the United States? . . We do it because we now know the industry is global . . We do it to provide flexibility and speed of response. We do it to better serve the diverse needs and values of individual markets and regions. We do it to take advantage of the contimuing ebb and flow of feedstock availability and cost. . . . The reward of global investment in the chemical industry is that you get to stay in business-the risk is that if you don't, you won't. It has become an admission fee to get into the game-not an expensive optional choice (Cook 1993). 


\subsection{Driver: Environmental Requirements Affect Capltal Investment and Product Development}

As noted previously, the chemical industry is subject to a large number of environmental regulations. Increasing public attention to environmental issues, combined with regulatory initiatives, has created strong pressure for action on the environmental front. These pressures manifest thenselves not only as mandates governing chemical indestry operations, but also as demands by customers for products that are developed using environmentally benign processes and that help them meet environmental requirements.

Increasing and evolving regulations are seen as a significam chaflenge by the chentical industry. Such regujations are forcing companies to increase spending on technologies and ptant upgrades to comply with new regulations impacting fuel formulation, air and water emissions, and waste handling. (see Table 3.1). The Commerce Department reports that capital expenditures for pollention abatement and control in the chemical industry almost tripled between 1985 and 1991 (see Table 3.2).

Further increases in enviromental spending are expected. In March 1994, for instance, EPA jssued a new mile requiring U.S. chenical plants to cut toxic substances emitted into the air by $88 \%$. As a result, companies will need to install new scrubbers, evaporation barriers, or other forms of pollution prevention technology. These new jegulations are estimated to cost fims between $\$ 680$ million to $\$ 1$ billion a year to comply (Lee 1994).

In many cases, the need to controt costs requires producers to pry more attention to waste minimization and process changes that recuce pollutant use and genteration as alternatives to end-of-chepipe controls. At the same time, customers' demands for products that help them meet environmental requirements compel firms to be environmentally focused in their product development. Marly customers, for instance, are demanding increased quantities and numbers of solvent-free and warer-based products.

Environmental requirements can sometimes have a significant impact on the industry by creating altogether new or expanded market opportunities. For example, the market for hydrogen is expected to surge over the next decade as petrolenm refiners upgrade gasoline to meet new Ciean Air Act requirements. Methanol markets also are expected to grow with the advent of methyl-tertiary-butyl-ether as an oxygenated fuel additive. Moreover, while the industry is deeply concerned about EPA proposals and public pressure to restrict or ban the use of chlorine in such uses as water disinfection, solvents, plastics, and pulp and paper manufacturing, those companies that have developed altematives to chlorine in these applications could benefit greatly (Hilieman and Hanson 1994).

Future environmental requirements are expected to be ixcreasingly stringert. New developments in chemical processes and technology are viewed as key to the industry's ability to meet these requirements and remain competitive. For example, a chemical company executive, speaking at a January 1994 U.S.-Russia Workstop on Envirommental Catalysis, stated that industrial facilities face two major 
Table 3.1. Environmental Spending by Company - 1992(a)

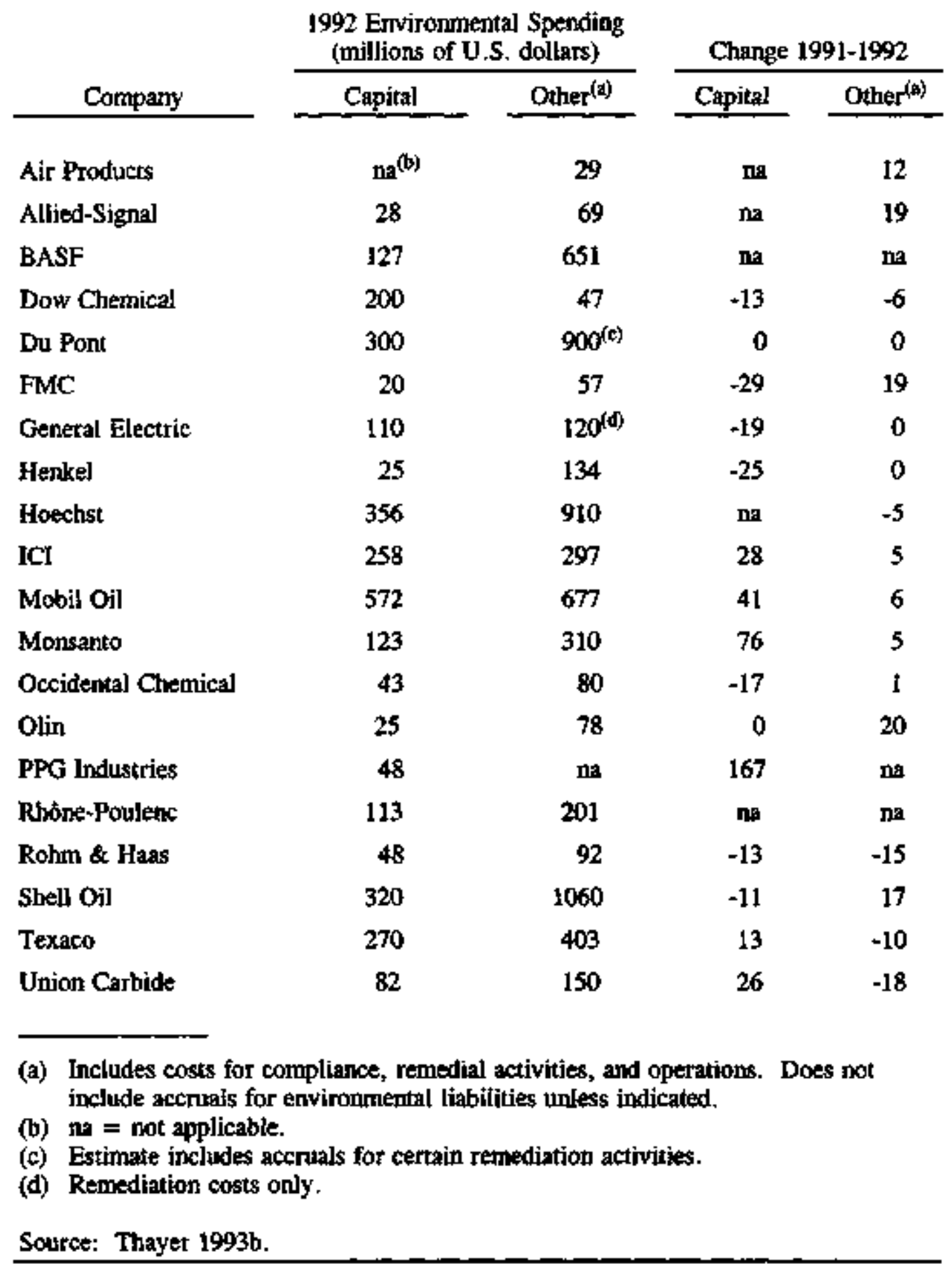


Table 3.2. Capital Expenditures for Poljution Abatement in the Chemical Industry (millions of U.S. dollars)

$\begin{array}{lllllllllll}1980 & 1982 & 1984 & 1986 & 1988 & \underline{1990} & \underline{1991} & \underline{1980-91} & 1980-85 & 1986-91 \\ 781 & 628 & 418 & 624 & 1,095 & 1,852 & 2,066 & 9.25 \% & -1.1 \% & 27.1 \%\end{array}$

Source: Bureau of the Census Data from CMA 1993.

challenges: cleaning up the effects of past manufacturing problems and minimizing the waste from current processing. He noted that, in the future, the industry will have to develop zero-waste processes, minimize the use and transportation of hazardous materials, and develop inherently safer products as well as to satisfy stockhoiders (Haggin 1994).

\subsection{Strategy: More Spending is Required on Environmental Protection}

To comply with increasingly stringemt environmental regulations, most companies are working on improving the environmental perfomance of their own intemal manufacturing processes and working with clients to develop new products that conform to new regulations.

Chemical companies are making great efforts to reduce both emissions and wastes and are spending more money on environmental protection. Some companies have committed additional funds to upgrading facilities and maximizing the efficiency of their manufacturing processes to comply with environnental regulations. For example, the Commerce Deparment reports that. in 1991, the chemical incustry's capital expentitures for pollution abaterneat and control reached $\$ 2.1$ billion, which represented approximately $10 \%$ of the industry's fixed capital investment (CMA 1993). The passage of the Clean Air Act in 1990 may result in the industry's investing up to 25-30\% of fixed capital on pollution abatement and control (CMA 1993). According to the U.S. Department of Commerce, more than $90 \%$ of pollution control spending is for abatement, including prevention, recycling, and treatment. The remaining $10 \%$ is for regulation, monitoting, and R\&D (Thayer 1993b).

\subsection{Strategy: Industry-Wide Programs Help Ensure Environmental Compliance}

Recent years have seen a greater emphasis within the industry on pollution prevention and avoidance as companies develop new ways of preventing the release of hazardous emissions and 
wastes. Changes are being made in the areas of materials havdling, maintenance, management, and operating practices. When possible, companies may try to substitute less hazardous materials for toxic ones, such as chlorofluorocarbons (CFCs) and methyl chloroform. Many firms have also increased their use of recycling or have begun to purify wastes rather than dispose of them.

This strong trend toward environmental awareness began in the early 1980s, In his speech to industry exccutives in June 1983, outgoing CMA chaiman Bill Simeral said that it was time for the chemical industry to take a look at the industry from the perspective of the American public. Although the chemical industry was actually one of the safest in the country, based on an anuual rating by the National Safety Council, most Americans nonetheless associated chenical manufacturers with leaking dump sites and environmental degradation. This was especially true after the Bhopal disaster in 1984. Simeral argued that unless the industry addressed public concerns head on, such images were likely to have a negative impact on the industry as a whole, which could affect everything from sales to recruitment (Rayport and Lodge 1991). Such attitudes provided the impetus for the development of CMA's Responsible Care Program, initiated in 1988. The aim of Responsible Care was to help achieve ongoing feductions in the amount of contaminants released into the air, water, and land from member companies' facilities (Thayer 1993b).

Responsible Care represents an industry-wide effort to improve performance and restore public trust in six key areas. A series of codes identify 106 management practices that members must carry out in these areas: 1) community awareness and emergency response, 2) pollution prevention. 3) process safety, 4) distribution, 5) employee health and safety, and 6) product stewardship (see Table A.8). The meribers of CMA (about 180 in alt) are required to strive to reduce waste generation and poliutants released at each of their plants. Funther, they must report arnually to the CMA on the volume of substances released at their facilities. To date, the Responsible Care Program has been adopted in more than 20 coumtries.

Responsible Care receives broad industry-wide support. Sraller, non-CMA-affiliated compantes have also begun to adopt the tenets of Responsible Care. Another industry trade group, the \$ynthetic Organic Chemical Manufacturers Association (SOCMA), whose membership generally is made up of firms with sales less than $\$ 40$ million, also promotes members' adtherence to the Commumity Awareness/Emergency Response code of the Responsible Care Program and has begun developing implementation tools for the other five Responsible Care codes (SOCMA 1993).

Although SOCMA members support Resporsible Care, they often face impletwentation challenges that CMA members do not face. These smalter companies do not always have sufficient capital and staff to handle the new demands associated with Responsible Care. Nevertheless, compliarce is considered to be very important, because it is beconing increasingly difficult for companies not impiementing Responsible Care codes to compete with those that do.

In addition to Responsible Care, various other industry-wide initiatives are aimed at helping companies improve their environmental records and promote public awareness. The Society of the 
Plastic Industry sponsors a progran called Operation Clean Swep, which is designed to eliminate the loss of resin pellets from mamufacturing facilities and transportation equipment into the environment, where they can be ingested by wildlife. Likewise, the American Plastics Council supports an industrywide program to promote the responsible use, recovery, and conservation of plastics. 


\subsection{Effects of Drivers and Strategies on Industry Research and Development}

The driving forces discussed in the previous section, and the strategies the chemical industry is using to respond to them, are leading the industry toward a particular future. As discussed in Section 5.0, the industry is in the process of articolating a vision of its desired future. However, at this time some elements of this fulure are evident and can be stated as follows:

- a lean, cost-conscious, and productive industry

- an industry that achieves high levels of customer satisfaction through product quality and innovation to meet customer requirements, particularly environmental neds

- an industry that comperes in the global marketplace, with expansion and joint ventures targeted to meet offshore market needs

- an industry that is a good steward of the environment, using technology and innovation to prevent pallution and avoid waste.

Achieving this future will require developinent of advanced technologies and processes that will boost efficiency and environmental performance while simsttaneously reducing energy and resource use and cutting industry costs (DOE 1994). Such developments will require sustained R\&D investments targeted at high-priority areas.

The U.S. chemical industry invests heavily in R\&D. In 1992, the industry spent an estimated $\$ 14.1$ billion on R\&D. The federal government also actively supports chemical research. In 1993, the U.S. govermment spent about $\$ 950$ million on chenical-related R\&D (Brennan and Long 1993). A small percentage of this total went to contract research at industrial laboratories; however, most federal funds for chemical R\&D supported research at universities and federal laboratories. ${ }^{\text {(a) }}$

(a) Four agencies provide over 70\% of these funds: the U.S. Departnent of Energy (21\%), U.S. Department of Defense (16\%), U.S. Department of Health and Human Services-National Institutes of Health (14\%), and the National Science Foundation (NSF) (20\%) (Brennan and Long 1993). Most NSF funding is directed toward university research. The NSF provides approximately $47 \%$ of federal funds for chemical research at universities, while the Departments of Energy, Defense, and Health and Human Services provide the rest (Brennan and Long 1993). In 1992, the academic sector spent approximately $\$ 16$ billion on chemical-related research, down slightly from the previous year. The majotity of these funds, over $62 \%$, were spent on basic research (Brennan and Long 1993). 
However, in spite of the need for R\&D to achieve its desired furure, overall spending for R\&D within chemical companies has been gradually decreasing, a trend that is expected to continue until at least the middle of the decade. A recent survey of 24 major chemical companies revealed that R\&D is estimared to fall an average of $1.4 \%$ in 1994 (Thayer 1994). Although another survey of the industry as a whole (including both large and small firms) has indicated that R\&D spending is still slowly rising. most industry analysts conclude that, on the average, companies are investing less in research and development. Part of this decrease is because of the recession that took hold in 1991 . When costs must be reduced, expenses viewed as non-revenue producing get cut first. In such an envitonment, spending on R\&D suffers because it is considered non-revenue producing, especially in the near term (Thayer 1994).

In response, many companies have allocated more money to technical service costs and product extensions or upgrades (see Table 4.1). As mentioned earlier, this is, in part, a consequence of focusing on customer satisfaction and on shifts into specialty chemicals, which require more technical service than do commodity chemicals. This often means that less money is available for R\&D activities in areas such as new chemistry and other long-term tesearch (Mullin 1992).

Another reason for the general decline in longer term R\&D budgets within the chemical industry is that firms are under greater pressure to comply with increasing environmental regulations, and the costs assocjated with compliance can be high. For example, in 1991, total U.S. poliution abatement and control spending arnounted to about $2.0 \%$ of GNP. The EPA estimates that this spending will rise to about $2.8 \%$ of GNP by the year 2000 , and this does not include the cost of compliance-related $\mathrm{R} \& \mathrm{D}$, the costs of following and interpreting regulatory thanges, legal expenses, and the costs of obtaining pernits (CMA 1993).

Table 4.1. R\&D Budget Allotments

Fraction of Total R\&D Budget Alloted to

Each R\&D Category

\begin{tabular}{|c|c|}
\hline$\overline{1981}$ & 1991 \\
\hline $30 \%$ & $45 \%$ \\
\hline $5-10 \%$ & $22 \%$ \\
\hline$<5 \%$ & $11 \%$ \\
\hline $5-10 \%$ & $12 \%$ \\
\hline $45-55 \%$ & $10 \%$ \\
\hline
\end{tabular}

Source: Mullin 1992. 
At the sarne time that chemical comparies are reducing their overall R\&D expenditures, many are also changing the way in which they conduct research. They are increasingly looking to outside sources to help leverage their financial resources. There is a growing trend toward contracting with outside performers, such as universities and independent laboratories, and toward participating in joitut R\&D ventures with other companies having sitnilar interests. Some firms have also begm to tap into the resources of the federal laboratories. These arrangements help expand companies' technological bases while at the same time reduce R\&D costs. Industry experts predict that more and more firms will form alliances in noncompetitive areas to develop technologies that can benefit the entire industry (Thayer 1994). Chernical companies will also have greater incentives to collabotate with the federal govermment to develop and deploy new technologies.

The OIT's "Industries of the Future" program builds on this movement toward collaboration among firms and with the federal govermment. The program will advance the state of chemical technology by (DOE 1994):

- catalyzing and facilisating collaborative, integrated planning and implementation of technologies by industry, goverament, and other participants

- conducting RD\&D through partnerships with industry participants as well as by focusing competencies of the fecteral laboratories on industry applications

- disseminating technology and information to stimulate broad commercialization of technologies. 


\subsection{Next Steps}

As described in Section 1.0, the CMA, the ACS, AIChE, and other groups together are leading an industry-initiated effort to develop a vision and roadmap for change for the U.S. chemical industry. This effort, which is occurring concurrent with the "Industries of the Future" effort for the chemical industry, will provide vital input to the OIT program.

As the next step in the strategy development effort for the chemical industry, OIT will furst summarize the results of recent efforts to obtain input from the chemical industry on its technology needs. It will then discuss technology needs with industry leaders, individually and in panels, in the context of the drivers discussed in this report, the vision being developed by industry representatives, and the technology needs sermmary prepared by OIT. Industry needs related to working successfully with the federal government and federal laboratories wifl also be discussed. The groups involved in the vision effort will be sponsors and facilitators of this dialogue.

OIT will hold a public workshop to review these results with a broad range of stakeholders and seek feedback and additional input for strategy development and program planning.

Finally. OIT will use the input from these efforts to craft a strategy to focus DOE short-, medium-, and long-term RD\&D investments relevant to the chemical industry on the most important needs of the industry and to work collaboratively with industry and other partners to conduct these RD\&D activities. 


\subsection{References}

Ainsworth, S. February 6, 1993. "Oil Price Drop May not Benefit Petrochemicals." Chemical and Engineering News, p. 7.

American Institute of Chemical Engineers (AIChE). 1993. Superfund Reauthorization in the 103rd Congress: An AIChE Legislative Report. AIChE, Washington, D.C.

Anderson, E., and J. Ayers, 1992. Current Topics in Specialty Chemicals, 1992: Company \$rrategy, Cyclicality, and the Role of Technology. SRI Intemational, Menlo Park, California.

Anderson, E.V. December 13, 1993. "Foreign Trade - U.S, Chemical Trade Surplus Declines." Chenical and Engineering News, pp. 36-38.

ARCO Chemical Company. 1993. 1992 Ammal Repon. ARCO, Newtown Square, Pennsylvania.

B.F. Goodrich Cormany. 1992. 1992 Fact Book. B.F. Goodrich, Akron, Ohio.

Brennan, M.B., and J.R. Long. August 23, 1993. "Facts and Figures for Chemical R\&D." Chemical and Engineering News, pp. 24-53.

Chemical and Engineering News (C\&EN). June 28, 1993a. "Chemical Capital Spending Dropped Again in 1992," pp. 54-56.

Chemical and Engineering News (C\&EN). June 28, 1993b. "Facts and Figures for the Chenical Industry," pp. 38-83.

Chemical Engineering. October 1992. "ISO 9000: A New Road to Quality," pp. 43-47.

Chemical Manufacturers Association (CMA). 1991. "Respomsible Care: A Public Commitment." CMA, Washington, D.C.

Chenical Manufacturers Assocjation (CMA), 1992. "Energy and the U.S. Chemical Industry." CMA, Washington, D.C.

Chemical Mantafactuters Association (CMA). 1993. U.S. Chentical Industry Statistical Handbook 1993. CMA, Washington, D.C.

Chemical Manufacturers Association (CMA), 1994, The U.S. Chemical Industry Performance in 1993 and Outlook. CMA, Washington, D.C. 
Chemical Week. January 6-13, 1993a. "Looking for a Turnaround in Chlor-Alkali," pp. 30-32.

Chemical Week. Jamuary 6-13, 1993b. "Forecast 1993," p. 22.

Cook. E.G. 1993. "A U.S. Company's Perspective on Global Investment in the Fuels and Petrochemical Industry." Presented at the American Instinute of Chemical Engineers (AIChE) Spring National Meeting, Houston, Texas.

Grant Thornton Accountants and Management Consultants (Grant Thornton). 1992. "Survey of American Manufacturers Annual Report." New York.

Haggin, J. Febnary 14, 1994. "Catalysis Gains Widening Role in Environmental Protection." Chemical and Engineering News, pp. 22-30.

Hileman. B. and D. Hanson. February 7, 1994. "Curbs on Chlorine Sought; EPA Plan Outrages Chenical Makers." Chemical and Engineering News, pp. 4-5.

Lee, G. March 2, 1994. "EPA Tells Chenical Plants to Cut Toxic Emission 88\%." The Washington Post. p. A3.

Lenz, A. J. 1994. "The U.S. Chemical lndustry: Keystone of U.S. Manufacturing." Presented at the Chemical Inqustry Analysts Workshop. January, 1994, Pacific Northwest Laboratory, Washington, D.C.

Monsanto Company. 1993. 1992 Annual Report. Monsanto, St. Louis, Missouri.

Mulliu, R. July 22, 1992. "Specialty Chemicals: Playing to Global Strengths." Chemical Week, pp. 22-23.

Nalco Chemical Company. 1993. I992 Annual Report. Nalco, Naperville, Illinois.

Occidental Petroleum Corporation. 1993. J992 Annual Report. Occidental, Los Angeles, California.

Office of Techoology Assessment (OTA). 1993. Industrial Energy Efficiency. U.S. Government Printing Office, Washington, D.C.

Rayport, J.F., and G.C. Lodge. 1991. Responsible Care. Harvard Business School Case Study, 9-391-135, Harvard Business School, Boston, Massachusetts.

Synthetic Organic Chemical Manufacturers Association (SOCMA). December 6, 1993. "ISO 9000 Registered Companies Report Cost Benefits." SOCHA Newsletter, p. 2. 
Synthetic Organic Chemical Manufacturers Association (SOCMA). 1993. Annual Report I992-I993. SOCMA, Washington, D.C., p. 2.

Thayer, A.M. March 1, 1993a. "Vajue of Global Quality Standards Becomes Clear to Industry." Chemical and Engineering News, pp. 12-17.

Thayer, A.M. July 26, 1993b. "Growing Exchange of Information Spurs Pollution Prevention Efforts." Chemical and Engineering News, pp. 18-25.

Thayer, A.M. Jamuary 24, 1994 . "Chemical Industry R\&D Spending to Fall Slightly in 1994." Chentcal and Engineering News, pp. 15-18.

U.S. Department of Commerce (DOC). 1989, 1989 Annual Sunvey of Manufactures, M89(AS)-I. U.S. Government Printing Office, Washington, D.C.

U.S. Department of Conmerce (DOC). 1992. Industrial Outlook 1992, U.S. Government Printing Office, Washington, D.C.

U.S. Department of Energy (DOE), 1994. "Industries of the Future: Energy Efficiency for Our Sustainable Future." DOE, Washington, D.C. 
Appendix A

Tables 
Table A.1. Companies Whose 1992 Annual Reports Were Reviewed ${ }^{(a, b)}$

Air Products and Chemicals, Inc.

International Flavors and Fragrances

Amoco Corporation

Atlantic Richfield Company (ARCO)

Lubrizol

Ashland Oil

Mobil Chenical

B.F. Goodrich

Monsanto

Chevron Corporation

Cyanamid

Dow Chemical

Morton

Nalco Chenuical Co.

Du Pont

Occidental Petroleum

Praxair, lnc.

Proctor and Gamble

Eastman-Kodak

Ethyl Corporation

Quantum Chemical Co.

Exxon Corporation

Rohm and Haas

General Electric

Shell Oil Company - Chetnical Products

Texaco, Inc.

Great Lakes Chemical

Union Carbide

Hercules, Inc.

W. R. Grace \& Co.

Hoechst Group

(a) With one exception, the review of anrual reports was linited to U.S.tbased companies, although virtually all these organizations have facilities located in various countries aroury the world. The one non-U.S.-based corporation, Hoechst Celanese, is headquartered in Germany but has substantial operations in the United States.

(b) Many of these companies also had significant non-chemical businesses; oil, electronics, aerospace products, and energy systems, to name bus a few. However, this review and the strategy development effort are concerned with only the chemicals divisions of U.S. companies. 
Table A.2. Standard Industrial Classifications Major Group 28 - Chemicals and Allied Products (e)

Industry Segment

- Industrial inorganic chemicals (8 companies)

Alkajies and chlorine

Industrial gases

Inorganic pigments

Industrial inorganic chemicals, n.e.c. ${ }^{\text {(b) }}$

- Plastics materials and synthetic resins, synthetic rubber, cellulosic and other manmade fibers, except glass (19 componies)

Plastics materials, synthetic resins and nonvulcanizable elastomers

Synahatic rubber (vulcanizable elastomers)

Celjulosic manmade fibers

Manmade organic fibers, except cellulosic

- Drugs (c) 9 companies)

Medicinal chemicals and botanical products

Pharmaceutical preparations

In vitro and in vivo diagnostic substances

Biological products, except diagnostic substances

- Soaps, detergents, and cleaning preparations; perfumes, cosmetics, and other toilet preparations (8 companies)

Soap and other detergents, except specialty cleaners

Specialty cleaning, polishing and sanitation preparations

Surface active agents, finishing agents, sulfonated oils, and assistants

Perfumes, cosmetics, and other toilet preparations

- Paints, varnishes, lacquers, enaniels, and allied products (3 companies)

- Industrial organic chemicals (14 companies)

Gum and wood chemicals

Cyclic organic crudes and intermediates, and organic dyes and pigments

Jndustrial organic chemicals, n.e.c.
SIC Code 
Table A.2. (contd)

- Agricultural chemicals (I2 companies)

Nitrogenous fertilizers

Phosphatic fertitizers

Fertilizers, mixing only

Pesticides and agricultural chemicals, n.e.c.

- Miscellaneous Chemical Products (7 companies)

Adhesives and sealants

Explosives

Printing ink

Carbon black

Chemicals and chemical preparations, n.e.c.

(a) Numbers in parentheses indicate the number of companies whose annual repors were reviewed that produced chemicats in each 3-digit SIC category.

(b) n.e.c. = not elsewhere classified.

(c) This SIC code was addressed only to the extent that some companies whose reports were revjewed had pharmaceutical operations. For purposes of strategy devejopment, however, the pharmaceuticals industry per se will not be examined. 
Table A.3. The Chenicals Industry Today

\section{Dimienstons}

- Produces 1.8\% of U.S. GDP and 10\% of all U. S. manufacturing; total shipments reached $\$ 297$ billion in 1992

- Inclutes 12,000 plants producing 70,000 chemicals: $95 \%$ produced in 2,000 batch facilities

- Inclades $170 \mathrm{U}$. S. companies wilh more than 2,800 facilities abroad; $\mathfrak{i}, 700$ foreign subsidiaries or affiliates are operating in the U.S.

- Exported $\$ 44$ bilition and imported $\$ 27$ billion in 1992; 29\% of thernational trade is intra-company; over $20 \%$ of trade is with Canada and Mexico (\$8.5 billion exprorted and $\$ 4.8$ hillion imported)

- Concemrales 63\% of production in 10 slates: TX, NI, LA, LL, OH, CA, NC, PA, NY, IN; t0\% of basic chernicals are produced in the Gull Coast region

Invested $\$ 23$ billion in 1992 on new planes and equipment, $\$ 6.6$ billion by U. S. companies abroad

- Investept 514 billion in R\&D in 1992

\section{Enerey}

- Total energy needs equivalent to 2.6 million bartels of crude oit per day; crude oil and derivatives, $45 \%$; natural gas, $30 \%$; electricity, 17\%; enal, 6\%: others, $2 \%$

- Consumed $\$ .5$ quads in 1992 ( 7 \% of total U.S. energy consumption); 2.6 quads for feedstocks, 2.9 quads for fuel/power

- Fuel/power costs as a fraction of production costs quite variable; e.g., high for industrial gases $(40-50 \%)$, lower for industrial organic chemicals $(<10 \%)$

Employment

- Employed 1,084,000 in 1992; 1,075,000 th 1982; declines at major companies for thitd straight year and significant restructurimg; only the drugs seckor showed growit (3\% aversige Rnnual) over past ten yeass

- Uates labor less inkensively than other maurafacturing industries (prodtection workers $53 \%$ of total emplayment vs. $68 \%$ for all menufacturing)

Earirommental

- Has regulatory costs growing faster then thity ather componeth of most ctpitzl budgets; $20 \%$ of 1992 capilal expenditures of $\$ 2 S$ bilfion was for envirowmental abatement or compliance

- Has significant emigsioas: 1991 annual, in millions of metric tons: $\mathrm{SO}_{2}, 20.7 ; \mathrm{NO}_{\mathrm{x}}, 18.8 ; \mathrm{vOC}, 16.9 ; \mathrm{CO}, 62.1$; particulates, 7,$4 ;$ tead, 5.0 thousant metric ons; annual rates are declining

- Docreased toxic emissions 35\% between 1987-1991 as defined by EPA's Toxic-Release Inventory Reponing Program 35\% between t987-1991, while production rose $11 \%$

- Performs extensive ontreach for contimsous envinonmemtal, heath and stfety performance improverment through CMA.developed Responsible Cate" Economics

- Yalues energy costs at only 8 \% of industry shipments

- Value added $\$ 88$ biltion in 1990 (1987 \$)

- Experienced declining earaings; profit margins and return on sharebokders' equity declined in 1992 for 4 th consecutive year 
Table A.4. Major Environmental Statutes Affecting the Chemical Industry

Emergency Planning and Community Right-To-Know Act-Mandates emergency planning and requires reportimi of chemicals sfored and released to the environment (the Toxic Release Inventory).

Clean Air Act-Prohibits hazardous air pollutant emissions in excess of standards. The 1990 Amendments impose new standards on the chemical industry; regulations announced March 1, 1994, require chemical plants to cut their entssions of toxic substances by $\$ 8 \%$.

Toxic Suhstances Control Act-regulates the testing and manufacture of chemicak substances and mixtures.

Resource Conservation and Recovery Act-goverus the management of hazardous waste from generation to disposal.

Comprehensive Environmental Response, Liability, and Compensation Act-governs the cleanup of hazardous waste sites. Many cherrical companies have been named as Potentially Responsible Parties under the Superfund program

Clean Water Act-Govens discharges of pollutants into U.S. waters and discharges of pretreated wastewater into sewer systems.

Safe Drinking Water Act-Governs the Ievel of contaminants allowable in drinking water. Its standards are used in setting cleanup standards for contaminated sites.

Source: DOC 1992. 
Table A.5. Chemical Industry Stakeholders

Suppliers

Materials, Equipment and Services Suppliers for the Chemical Process lrdustries, other Producers

Producers

Industrial bxorganic Chemicals; Plastics Materials and Synthetic Resins, Synthetic Rubber, Cellulosic, other Mammade Fibers (except glass); Drugs; Soaps, Detergents, Cleaning Preparations; Perfurnes, Cosmetics, Toilet Preparations; Paints, Varnishes, Lacquers, Enamels; Industrial Organic Chemicals; Agricultural Chemicals; Miscellareous Chemical Products

\section{Customers}

Agricultural, Construction, Manufacturing, and Service Industries, Consumers, other Producers

Trate Associations

Chemical Manufacturers Association, Synthetic Organic Chernical Manufacturers Association, Chemical Specialties Manufacturers Association, Cosncil for Chemical Research, Industrial Research Institute, Phatracentical Manjfacturers Association, Soap and Detergent Association, Chlorine Institute. The Society of the Plastics Industry, others

\section{International Organizations}

International Chamber of Commerce, International Organization for Standardization (ISO), others

Academic/Research Institutions

U.S. Colleges and Universities, National Laboratories (Argome National Laboratory, Idaho National Engineering Laboratory, National Renewable Energy Labotatory, Oak Ridge National Laboratory, Battelle Pacific Northwest Labaratory), Research Triangle Institute, Southovest Research Institute, others

Public Interest Gronps

Sierra Club, Greenpeace, Envirommental Defense Fund, Natural Resources Defense Council, Friends of the Earth, Nature Conservancy, others

\section{Government Agendes}

Department of Energy, Departinent of Commerce, Department of Health and Human Services (FDA), Department of Defense, Department of Labor (OSHA), Department of Agriculture, Environmental Protection Agency, National Science Foundation, NASA

\section{Professional Sacieties}

American Chemical Society, American Institurte of Chemical Engineers, American Institute of Plant Engineers, American Academy of Envíronmental Engineers, others

Shareholders

Individual and Institutional Investors, Financial Services Sector 
Table A.6. Elements of ISO 9000

ISO 9001: specifies quality assurance in design, production, installation and servicing a product

ISO 902: applies to production and installation

1SO 9003: applies to final inspection and testing

ISO 9004: provides quality management and system elements needed to develog and implement a quality system. Also determines the extent to which each system element is applicable.

Seven steps to ISO certification:

1. Compare current procedure to standards $9001-9003$.

2. Identify the steps needed to bring them into conformance with the applicable standards.

3. Prepare a quality assurance program.

4. Define, document and implement the new procectures.

S. Prepare the Quality Marazal.

6. Arrange a preassessment meting with the chosen auditor to analyze the Quality Manual.

7. The certification audit.

Source: Chemical Engineering 1992 
Table A.7. ISO 9000 Certification at U.S. Chemical Companies

\begin{tabular}{|c|c|c|c|c|c|}
\hline \multirow{2}{*}{ Company ${ }^{(a)}$} & \multicolumn{2}{|c|}{ Registrations } & \multirow[b]{2}{*}{ Company ${ }^{(a)}$} & \multicolumn{2}{|c|}{ Registrations } \\
\hline & U.S. & Non-U.S. & & U.S. & Non-U.S. \\
\hline \multirow{2}{*}{$\begin{array}{l}\text { Air Products \& } \\
\text { Chemicals }\end{array}$} & $7^{(b)}$ & 36 & Monsanto & 2 & l \\
\hline & & & Nalco Chemical & 4 & $18^{(h)}$ \\
\hline Altied-Signal & 2 & na & Occidental Chemical & $3^{(i)}$ & $2^{(0)}$ \\
\hline Arco Chemical & 0 & $5^{(\mathrm{c})}$ & Philjips & 3 & 3 \\
\hline BASF & 1 & 8 & PPG Industries & 2 & 2 \\
\hline Dow Chemical & $2^{(d)}$ & 58 & Praxair & 3 & 6 \\
\hline Dut Pont & $64^{(t)}$ & $>100$ & Rhône-Poulenc & 1 & $32^{(\mathrm{h})}$ \\
\hline Eaștman Chemical & 5 & 1 & Rohm \& Has & 4 & 14 \\
\hline Engelhard & 2 & 3 & Solvay lnterox & 3 & 1 \\
\hline Exxon Chemical & 11 & $60^{(0)}$ & Texaco Chemical & 4 & 3 \\
\hline FMC & $5^{(\mathrm{e})}$ & 7 & Union Cartide & 21 & 10 \\
\hline Hercules & 2 & 2 & Vulcan Chemicals & 3 & 0 \\
\hline Hoechst Celanese & 7 & 2 & Witco & 2 & 1 \\
\hline lCI & 3 & $>270$ & W.R. Grace & 0 & $\$ 3$ \\
\hline \multicolumn{6}{|c|}{$\begin{array}{l}\text { (a) Representative listing for late } 1992 \text {-earyy } 1993 \text {. Most certifications are ISO } \\
\text { otherwise noted and when available from company data. } \\
\text { (b) Includes one multisite registration involving more than } 100 \text { facilities in the } \\
\text { Canada. } \\
\text { (c) Includes ISO } 9001 \text { registrations for research facilities and headquarters. } \\
\text { (d) Includes facility in joint venture with Exxon Chemical; included in Exxon } \\
\text { (e) Includes Il ISO } 9001 \text { registrations. } \\
\text { (f) Company estimate. } \\
\text { (g) One } 1 \$ O \text { 9001 certification. } \\
\text { (b) Includes several ISO } 9001 \text { registrations. } \\
\text { (i) Includes plant in joint venture with Du Pont. } \\
\text { (j) Includes registration for intemational sales operations in several countries. } \\
\text { na = not available. }\end{array}$} \\
\hline
\end{tabular}


Table A.8. Guiding Principles of Responsible Care

- To recognize and respond to conmunity concerns about chenticals and plant operations.

- To deveiop and produce chemicals that can be manufactured, transported, used, and disposed of safely.

- To make health, safety, and environment considerations a priority in plaming for all existing and new products and processes.

- To report pronptly to officials, employees, customers, and the public, information on chenical-related health or environmental hazards and to recontuend protective measures.

- To counsel customers on the safe use, transportation, and disposal of chemical products.

- To operate plants and facilinies in a manner that protects the environment and the health and safety of employes and the public.

- To extend knowledige by conducting or supporting research on the health, safety, and environmentat effects of ptoducts, processes, and waste materials.

- To work with others to resolve problens created by past handling and disposal of hazardous substances.

- To participate with government and others in creating responsible laws, regulations and standards to safeguard the community, workptace, and environment.

- To promote the principles and practices of Responsible Care by sharing experiences and offering assistance to others who produce, handle, use, transport, or dispose of chemicals.

Source: CMA 1991. 


\section{Distribution}

No. of

Copies

Offsite

12 DOE/Office of Scientific and Technicat Information

5 Air Products and Chemicals, Ine. 7201 Hamilton Bivd. Altentown, PA 18195-1501

Atn: C.E. Anderson

T. A. Manpel

R. N. Miller

S. M. Mortis

G. Pez

A, M. Alanko

Dow Corning Corporation

Mail $\mathrm{FC40D003}$

Midtand, MI 48686-0994

\section{A. Amarnath}

EPRI

3412 Hillview Avenue

Palo Alto, CA 94304-1395

4 American Chemical Society

1155 16th \$t., NW

Washington, D.C. 20036

Atan.: M. Panar

S. M. Turner

D. L. Schutt

S. Baker

3 American Institute of Chemical

Engipeers

1300 I Street, NW, Stite 1090 East

Washington, D.C. 20005

Attr:

S. Bersell

D. E. Brooks

G. L. Lederer
No. of

Copies

R. D. Andrew

Mobil R\&D Corporation

P.O. Hox 1026

Princeton, NJ 08543

P. Angelini

Oak Ridge National Laboratory

P.O. Box 2008

Oak Ridge, TN 37831-6273

4 Argonme National Laboratory

9700 South Cass Ave., ES/362

Argonne, IL 60439-4815

Attn: M. Petrick

D. K. Schmalzer

W. W. Scherts

N. F. Sather

S. P. J. Ashkin

Vice President

Rochester Midland

P.O. Box 1515

Rachester, NY 14603-1515

K. Baker

Baket \& O'Brien, Inc.

14900 Landmark BJvd.

Suite 510

Dallas, TX 75240

L. M. Baker

Praxair, Inc.

39 Old Ridgebury Road

Danbury, CT 06810-5113

M. Baker

EPRI-Chemicals \& Petroleum Office

1775 St. James Place

Suite 105

Houston, TX 77056 
No, of

Copies

R. Baker

MTR

1360 Witlow Road

Menło Park, CA 94025

E. J. Bassler

Stone \& Webster Engineering

Corporation

245 Summer Street

Boston. MA 02210

A. T. Bell

University of California

College of Chemistry

420 Latimer Hall

Berkeley, CA 94720-1460

R. Benson

Los Alamos National Lahoratory

P.O. Box 1663

Los Alamos, NM 87545

A. S. Brandegee

Brandegee, Inc.

10 Bedford Square

Pittsburgh, PA 15203

R. Breault

Tecogen, Inc.

45 First Avenue

P.O. Box 9046

Waltham, MA 02254-9046

T. J. Brett

Uniroyal Chemical Company

World Headquaners

Middlebury, CT 06749

B. Burke

Chem Systems, Inc.

303 S. Broadway

Tarrytown, NY 10591
No. of

Copies

R. S. Butner

Shapiro and Associates

1201 Third Avenue, Strite 1700

Seattle, WA 98101

4 Chemical Manufacturers Association

2501 M Street, NW

Washington, D.C. 20037

Atto.; D. T. Artemis

D. Kellogg

A. J. Lenz

T. Parker, Jr.

H. L. Chum

National Renewable Energy Laboratory

1617 Cole Boulevard

Golden, CO 80401

R. W. Chylla

SC Johnson Polymer

1525 Howe Street

M.S. 305

Racine, WI 53403

P. Ciccio

The Dow Chemical Company

1776 I Street, NW

Suite 575

Wastington, D.C. 20006

W. E. Clarke

Arthur D. Little

ADL

Açorn Park

Cambridge, MA 02140

C. B. Cobb

Wright Killen and Company

5847 San Felipe

Houston, TX 77057

F. P. Corson

Dow Chemical Company

Midland, MI 48674-1776 
No. of

Copies

\section{J. Covey}

Synthetic Organic Chemical

Manufacturers Association, lnc.

1330 Connecticul Avenue, NW

Suite $\mathbf{3 0 0}$

Washington, D.C. $20036-1702$

J. C. Davis

BP Oil

BP America, Inc.

Warrensville Rsh. \& Environ. Sci, Ctr.

Cleveland, OH 44128-2837

W. K. Davis

209 Fairhills Drive

San Rafael, CA 94901

\section{N. J. DeHaven}

Southern California Edison

Energy Effjeiency \& Market Services

$300 \mathrm{~N}$. Lone Hill Avenue

San Dimas, CA 91773

4 Department of Commerce

National lnstitute of Standards \&

Technology

Administration Building

Gaithersburg, MD 20899-0001

Attn: S. Abramowitz
L. B. Schilling
B. I. Diamondstone
H. G. Semerjian

\section{M. Detz}

Chevron Rsh. \& Tech. Company

Tech. Bassiness Planning

100 Chevron Way

Richmond, CA 94802-0627

\section{R. L. Dickenson}

SFA Pacific, Inc.

444 Castro Street, Sưte 920

Mountain View, CA 94041
No. of

Copies

T. R. Donselisy

American Plastics Council

1275 K St, NW, Suite 400

Washington, D.C. 20005

R. F. Drnevich

Praxair, Inc.

175 East Park Drive

P.O. Box 44

Tonawanda, NY 14151-0044

D. Eastman

Lonza Incorporated

1717 Route 208

Fair Lawn, NJ 07410

4 EG\&G-Idaho, Inc., INEL

P.O. Box 1625

ldaho Falls, ID 83415

AItn: E. Fleischman

T. W. Lawford

J. Mils

R. E. Rice

W. R. Epperly

Catalytica, Inc.

430 Ferguson Drive

Mountain Vjew, CA 94043-5272

L. Feder

Institute of Gas Technology

$1825 \mathrm{~K}$ Street, NW, Suite 503

Washington, D.C. 20006

W. W. Fletcher

Congress of the United States

Office of Technology Assessment

Washington, D.C. $20510-8025$

J. H. Futrell

Dept. of Chemistry and Biochemistry

University of Delaware

Newark, DE 19716 
No. of

Copies

A. Gelbein

Catalytica, Inc.

5109 Leesburg Pike

Suite 207

Falls Church, VA 2204 I

\section{J. J. Gersic}

U.S. International Trade Commission $500 \mathrm{E}$. Street, SW

Washington, D.C. 20436

L. R. Gess

NALCO Chemical Company

One NALCO Center

Napesyile, IL 60563-1198

C. R. Goetzman

Westinghouse Savannah River Company

Aiken, SC 29808

R. D. Goodin

Monsanto Company

800 N. Lindbergh Boulevard

St. Louis, MO 63167

\section{A. Hancock}

Sun Company, Inc.

Research \& Development

Box 1135

Marcus Hook, PA 19061-0835

R. W. Hankinson

Polymer and Materiats Division

Phillips Corporate Technology

Phillips Petrolesm Company

206 CPL PRC

Bartlesville, OK 74004
No. of

Copies

S. Harper

Environmental Protection Agency

401 M Street, SW, 6103

Washington, D.C. 20460

A. M. Hartstein

U.S. Department of Energy

Office of Oil and Gas Processing

Washington, D.C. 20585

V. F. Haynes

BF Gondrich Research and

Development Center

9921 Brecksville Road

Brecksville, OH 4414]

2 Hercules lnoorporated

1313 Market Strzet/12242SW

Wilmington, DE 19894-0001

Attn.: T. Bednarski

D. BJair

B. Herwig

Praxair

8615 Bradgate Road

Alexandria, VA 22308

C. T. Hill

RAND

$2100 \mathrm{M}$ Street, NW

Washington, D.C. 20037-1270

2 Hoechst Celanese Coqporation Advanced Tectinology Group

86 Morris Avenue

Summit, NJ 07901

Atth:

R. S. Jones

R. Rupp

Distr. 4 
No. of

Copies

B. Houston

Federation of Materials Societies

1899 L Street, NW, Suite $\mathbf{5 0 0}$

Washington, D.C. 20036

\section{J. L. Humphrey}

3605 Needles Drive

Austin, TX 78746

D. E. Jost

Council for Chemical Research, Inc.

I620 L Street, NW

Suite 825

Washington, D.C. 20036

P. C. Juliano

General Electric Company

Corporate Research and

Development Center

P.O. Box 8

Schenectady, NY 12301

T. M. Kaarsberg

Vista Technology, Inc.

1735 Jefferson Davis Highway

Crystal Square 3, Suite 807

Arlington, VA 22202

S. Kaminky

MacTec

1617 Cole Boulevard

Building 17

Golden, CO 80401

C. J. King

University of California

Department of Chemical Engineering

$200 \mathrm{Californiz}$ Hatl

Berkeley, CA 94720-9989

J. E. Kmiecik

Texacn Chemical Company

P.O. Box 27707

Houston, TX 77227
No. of

Copies

T. Koch

DuPont Chemicals

Experimental Station

P.O. Box 80336

Wilmington, DE 19880

F. C. Kokesh

Phillips Petroleum Company

$130 \mathrm{RF}$

Bartlesville, OK 74004

A, B. Krewinghaus

Shell Development Company

P.O. Box 1380

Houston. $7 \mathrm{X}$ 77251-1380

M. Ladisch

Purdue University

1295 Potter Building

West Lafayette, IN 47906

J. Lafirance

U.S. Department of Commerce

HCHB Room 4418

14th St. \& Constitution Ave, NW

Washington, D.C. 20230

M. R. Lindstrom

Phillips Research Center

239 RF

Bartelsvid]e, OK 74004

G. Maestas

Los Alamos National L.aboratory

P.O. Box 1663

Mail Stop F643

Los Alamos, NM 87545

L. Manzer

DuPont

Corporate Catalysis Center

Wilmington, DE 19880-0262 
No. of

Coples

V. Matteucci

Monsanto Company

$800 \mathrm{~N}$. Lindborgh

St. Louis, MO 63167

R. A. Matula

Institute of Paper Science \& Tech.

575 14th St., NW

Atlanta, GA 30318

K. McFadden

WR Grace and Company

7379 Route 32

Columbia, MD 21044

G. E. MeGraw

Eastman Chemical Company

Box $5: 1$

Kingsport, TN 37662

B. Mstlman

DOE-Basic Energy Sciences

ER-14, GTN MS-F240

Washington, D.C. 20585

W. G. Morin

National Association of Manufacturers

1331 Pennsylvania Ave, NW, $\$ 1500$

North Tower

Washington, D.C. 20004-1790

G. L. Mossman

Dixie Chemical Company

P.O. Box [304 10

Houston, TX 77219-0410

H. S. Muralidhara

Cargil! Research

Box 9300

Minneapolis, MN 55440

R. D. Noble

University of Colorado

Chemical Engineering Department

P.O. Box 424

Boulder, $\mathrm{CO} 80309$
No, of

Copies

J. Norontha

Architectural \& Engineering

Services Div.

Eastman Kodak Company

1669 Lake Ave,, 8th Floor, Bldg. 23

Rochester, NY 14652-4390

J. D. Oleson

Dow Corning Corporation

CO1330 - Dow Corning Center

Midland, MI 48686-0994

J. J. Pellegrino

NIST

Mail Stop 838.0]

325 Broadway

Boulder, CO 80303

G. R. Petersen

National Renewable Energy Lahoratory

Industrial Technolagies Division

1617 Cole Blvd.

Golden, CO 80401-3393

D. J. Raber

National Research Council

2101 Constitution Ave., NW

Washington, D.C. 20418

C. Rader

Occidental Chemical Company

2801 Long Road

Grand Island. NY 14072

R. Rolke

Shell Chemiçal Company

P.O. Box 1380

Houston, TX 77251-1380

M. C. Saft

Grace Specialty Cherticals Co.

919 38th St., NW

Suite 400

Washington, D.C. 20006

Distr. 6 
No. of

Copieg

T. Sampson

Amerifan Petroleum Institute

$1220 \mathrm{~L}$ Street, $\mathrm{NW}$

Washington, D.C. 20005

R. W. Schmeal

EPRI Chemical \& Petroleum Office

EPRI

1775 St. James Place

Suite [05

Houston, TX 77056

R. T. Schwartz

Laurel Industries, lnc.

30000 Charm Blvo.

Cleveland, OH 44124

C. T. Seiance

DuPont Research \& Development

Experimental Station, Bldg. 304/A303

P.O. Box 80304

Wilmington, DE 19880-0304

C. D. Scott

Oak Ridge National Laboratory

Director Bioproc. Rsh. \& Dev. Center

P.O. Box 2008

Oak Ridge, TN 37831-6226

C. Selby

Exxon Chemical Company

Basic Chersicals Group

P.O. Box 4900

Baytown, TX 77522 4900

R. Seltzer

Cibs Additives

Ciba-Geigy Corporation

444 Saw Mill River Road

Ardsley, NY 10502-2699
No. of

Copies

G. D. Shier

The Dow Chenical Company

1801 Building

Midland, MI 48674-1776

S. K. Sikdar

Water and Hazardous Waste

Treatment Research Division

Environmental Protection Agency

26 W. Martin Luther King Dr.

Cincinnati, OH 45268

G. W. Smith

Southeastern Louisiana University

SLU 784

Hammond, LA 70402

R. D. Smith

BP Chemicals lac.

200 Public Square, 30-E

Cleveland $\mathrm{OH} 44114$

P. D. Stone

The Dow Chemical Company

1776 Eye Street, NW

Suite 575

Washington, D.C. 20006

A. P. Sylwester

Sandia National Lahoratories

Albuquerque, NM 87185-0749

T. E. Tabor

The Dow Chemical Company

1776 Building

Midland, Mf 48674

E. F. Take

Mallinckrodt Speciality Chemicals

Company

16305 Swingley Ridge Dr.

Chesterfield, MO 63017 
No. of

Coples

J. W. Tipping

ICI Americas, Inc.

341 I Silverșide Road

P.O. Box 15391

Wilmington, DE 19850

W. J. Tracy

Process Environmental

Mobil R\&D Corporation

P.O. Box $\mathbf{4 8 0}$

Paulsboro, NJ 08066

J. A. Trainham

DuPont Central Research and

Development

Experimental Station

P. O. Box 80357

Wilmington, DE 19880-0357

U.S. Department of Energy

EE-20

1000 Independence Avenue. SW

Washington, D.C. 20585

Atur:
A. J. Streh
N. K. Cole
B. Cunningtam
L. J. Sousa
D. Swink
J. Atcheson

2 U.S. Department of Energy

EE-22

1000 Independence Avenue, $\mathrm{SW}$

Washington, D.C. 20585

Attn: K. D. Sisson

B. Beyma

$5 \quad$ U.S. Department of Energy

EE-221

1000 Independence Avenue, SW

Washington, D.C. 20585

Attn: W. P. Parks

R. C. Jain

S. L. Richlen

P. E. Scheihting

G. Varga
No. of

Copies

14 U.S. Department of Energy EE-222

1000 Independence Avenue, $\mathbf{S W}$

Washington, D.C. 20585

Attn:

K. D. Sisson

T. L. Johnson

C. Carwile

H. B. Cranford

T. Foust

S. Friedrich

D. Gish

T. Johnson

S. Leonard

S. L. Natof

C. Russomanno

A. C. Schroeder

M. Smith

F. W. Wilkins

4

U.S. Department of Energy

EE-223

1000 Independence Avenue, SW Washington, D.C. 20585

Attn: J. Duane

R. Butters

C. J. Glaser

M. L. Quint

2 U.S. Department of Energy

EE-23

1000 Independence Avenue, SW

Washington, D.C. 20585

Attn: P. H. Satmon-Cox

L. Dudley

4 U.S. Department of Energy

EE-232

1000 Independence Avenue, SW

Washington, D.C. 20585

Atten:

P. H. Salmon-Cox

D. Boron

E. H. Fu

C. Sortell

Distr. 8 
No. of

\section{Copies}

6 U.S. Department of Energy EE-233 1000 Independence Avenue, $\mathrm{SW}$ Washington, D.C. 20585

Attr: D. E. Wiley

J. DeWees

G. Kulesa

S. F. Sobczynski

B. Volintine

V. Wright

5 U.S. Department of Energy

EE-234

to00 Independence Avenue, SW

Washington, D.C. 20585

Attr: M. J. McMonigle

G. N. Jagtiani

D. Kaempf

W. A. Otrenchain

D. M. Pellish

2 U.S. Department of Energy

Idaho Fieid Office

785 DOE Place

Idaho Falls, ID 83402

Attn: W. Thielbahr

R. G. Trimberger

6 U.S. Department of Energy

Office of Basic Energy Sciences

Washington, D.C. 20545

Attn:

S. A. Butter, ER-142

C. Carth, ER-16

F. A. Koomanoft, ER-10

A. H. Laufer, ER-141

R. S. Marianelfi, ER-14

F. D. Stevertson, ER-142

F. A. Via

Corporate Research

Alvo Corporate Research America Ine.

Livingstone Avemue, Dobbs Ferty

New York, NY 10522-3401
No. of

Copies

J. Weaver

American Institute of Chemical

Engineers

345 East 47th St.

New York, NY 1001T

V. W. Weekman, Ir.

Mobil Oil Corporation

P.O. Box 1025

Princeton, NJ 08543

R. M. Wellek

National Science Foundation

$1800 \mathrm{G}$ Street, NW

Washington, D.C. 20550

J. K. Wesset

Dow Corning

$1800 \mathrm{M}$ Street, NW

Suite 325 South

Washington, D.C. 20036

H. F. Whalen, Jr.

The PQ Corporation

P.O. Box 840

Valley Forge, PA 19482

B. H. Wiers

The Proctor \& Gamble Company

Miami Valley Laboratories

P.O. Box 398707

Cincinnati, OH 45239-8707

I. Yagoobi

Texas A \& M University

College Station, TX 77843

Onsite

DOE Richland Operations Onfies

D. D. Green

K8-50 
No. of

Copies

146 Pacific Northwest Laboratory

C. R. Alten

K. P. Ananth

W. B. Ashton

E. G. Baker

J. E. Beck

T. B. Bergsman

H. Cialone

M. Clement

J. J. Dooley

J. A. Dorsey

T. H. Dunning

D. R. Eike

L. G. Elson

F. F. Eriar

G. J. Exarhos

J. A. Fort

J. A. Fox

K. A. Freund

B. A. Garrett

G. L. Graff

R. T. Hallen

B. A. Hedman

M. E. Hopkins

K. K. Humphreys

C. $\mathbf{H}$. Imhoff

A. K. Johnson (3)

B. R. Kinzey

T. L. Kuusinen

K. S. Lang

N. J. Lombardo

D. P. McConnell
No. of

Copies

S. C. McDonald Bwo

G. L. McVay X2-45

E. L. Malone BWO

P. M. Martin K3-59

N. L. Moore K8-04

A. K. Nicholls BWO

R J. Nesse K8-15

E. W. Pearson K1-57

M. Placet BWO

R. K. Quinn K1-73

L. M. Ramonas $\quad$ K1-71

R W. Reilly K8-54

J. T. A. Roberts K1-45

D. A. Shankle K8-1 ]

L. J. Sealock K2-10

B R. Shaw K6-88

E J. Stenehjent K8-04

L A. Stevenson BWO

M. K. Stockmeyer BWO

B. R. Strits K2-20

M. R. Thompson K2-50

A. Y. Tonkovich $\quad$ P8-38

J. W. Virden

S. C. Weiner (75) BWO

T A. Werpy $\quad$ K2-40

l. L. White BWo

C. L. Widrig K1-77

J. E. Widrig K8-04

W. R. Witey $\quad$ K1-82

E I. Wojtaszek BWO

M. G. Woodruff (3) BWO

Pubtishing Coordination

Technical Repert Files (5) 